\title{
Seasonal Variations in Planktonic Community Structure and Production in an Atlantic Coastal Pond: The Importance of Nanoflagellates
}

\author{
C. Dupuy ${ }^{1^{\star}}$, M. Ryckaert ${ }^{2}$, S. Le Gall ${ }^{1}$ and H. J. Hartmann ${ }^{1}$ \\ ${ }^{1}$ CRELA, UMR 6217, Pôle Science Av. Michel Crépeau, 17042 La Rochelle, France \\ ${ }^{2}$ DEL/IFREMER BP 5, 17137 L'Houmeau, France \\ * Corresponding author E-mail: cdupuy@univ-Ir.fr and Phone: 00 (33) 46457271 \\ Adress: Christine Dupuy, CRELA, UMR 6217, Pôle Science Av. Michel Crépeau, 17042 La Rochelle, \\ France
}

\begin{abstract}
:
The structure and summertime production of planktonic communities and the role of non-diatom planktonic cells were studied in coastal ponds, which are areas traditionally used for fattening and greening table-size oysters. The abundance and biomass of nano-microplanktonic protists were determined at weekly intervals between February 1998 and February 1999 in a coastal pond without oysters in French Atlantic coast near La Rochelle. The production of these microbiota were determined in summer period. The structure of plankton communities revealed that (1) microphytoplanktonic cells were mostly diatoms and dinoflagellates, (2) microzooplanktonic cells were mainly ciliates and (3) nanoplanktonic cells were represented by pigmented (80- $90 \%$ of the nanoplankton biomass) and colourless nanoflagellates. Diatoms were dominated by Naviculiineae. Dinoflagellates were dominated by Peridiniales. Oligotrichida were predominant in the ciliate community. Protist biomass levels were 9 times higher from April to August (summer period: $1033 \mu \mathrm{g}$ $\mathrm{C} \mathrm{L}^{-1}$ ) than from September to March (winter period: $114 \mu \mathrm{g} \mathrm{C} \mathrm{L}^{-1}$ ). Whatever the season, nanoflagellates were dominant in the water column (respectively $66 \%$ and $53 \%$ of the entire protist biomass in the summer and winter periods). Nanoflagellates represented the highest production of nano-microplanktonic communities (76\% of carbon protist production) in the coastal pond in summer as well as showing the shortest generation time $(7.1 \mathrm{~h})$. Dinoflagellates came after nanoflagellates in production (19.5\% of carbon protist production). Diatoms represented only a supplementary carbon resource available for higher trophic levels, whereas until now they were considered as the principal food of oysters in coastal ponds. Ciliates were a small source of carbon, but their growth rate was high. We suggest, firstly, that nanoflagellates represented the primary resource available in the pond and could constitute an important food resource for higher trophic levels, such as oysters, farmed in this type of pond. The system appeared to be more autotrophic than heterotrophic overall. Since inorganic nutrients are quickly exhausted in a semi-closed pond, pigmented flagellates dominated the carbon biomass, production and biomass of bacteria was high, so the microbial food web appeared to be active in this pond, and mixotrophy seemed to be an important trophic mode there.
\end{abstract}

Keywords: Coastal pond, nanoflagellates, microbial structure and production, food source. 


\section{Introduction}

Oyster farming is an important activity in Charente-Maritime, on the French Atlantic coast in Europe. Studies on coastal ponds, traditionally used for fattening and greening tablesized oysters [28], began in 1980. Microphytoplanktonic and microphytobenthic communities have often been studied in coastal ponds [7, 46, 47, 60,61] and bacterioplankton studied occasionally [8,9]. In semi-closed systems such as ponds where nutrients are quickly exhausted, the development of microphytoplankton is limited [47]. And although the microphytobenthic biomass can reach up to 25 times the higher levels of phytoplankton biomass $[47,61]$ in the water column, it is unlikely that the microphytobenthos is a significant direct source because of its low level of re-suspension, due to the lack of turbulence in rather than an intertidal zone [4]. Microalgae, usually considered as oysters' main food source, cannot entirely account for their energy requirements in Atlantic coastal ponds [24].

In recent years, interest in the ecological role of marine planktonic protists has increased, particularly for marine nanoplankton and microzooplankton in the microbial food web. Numerous studies have been made on the trophic link of microzooplankton and nanoplankton since they are preyed upon by many sorts of zooplankton, particularly copepods [3, 19, 22, 25, 57], bivalve larvae [27], and suspension-feeding bivalves, such as oysters, Crassostrea gigas $[11,33]$. Microzooplankton is considered to be an important grazer of nanoplankton [13] and bacterial production [49, 50]. Heterotrophic and mixotrophic nanoplankton are important grazers of bacteria [53].

In the Atlantic coastal ponds, $17 \%$ to $50 \%$ of the planktonic carbon biomass is made up of bacterioplankton [9, 17]. Such heterotrophic bacterioplankters, with typically high growth rates and efficiencies, represent a significant energy pathway by recycling DOM into particles potentially available to upper trophic levels, like nano-microzooplankton $[1,41]$. In addition, bacterioplankton are not held by oysters which retain particles between 5 and 100 $\mu \mathrm{m}[2,24,44,55]$. Thus, in Atlantic coastal ponds, nano-microzooplankton may represent a trophic link between bacteria and the higher trophic levels in the benthos, especially oysters [11].

The aim of this study was to determine the structure and production of planktonic communities and to estimate the significance of microphytoplankton, compared to nanomicrozooplankton, as a potential food source for oysters. Our experimental design was to monitor physical-hydrobiological parameters, abundance and biomass of phytoplanktonic and zooplanktonic communities in a coastal pond without oysters between February 1998 and February 1999 (12 cycles) on a weekly basis. Protist production was estimated in summer by incubation experiments as described by Landry and Hassett [29] and Ferrier-Pagès and Rassoulzadegan [15].

\section{Materials and Methods}

Study site

This study was performed in an experimental coastal pond without oysters called "Marais du Plomb" (L'Houmeau, near La Rochelle, French Atlantic coast). It was dug 15 years ago in clay sediment and the flat bottom is made up of thin layers of silt resulting from sedimentation of marine particles brought by turbid coastal waters, and destabilisation of the banks surrounding it. The pond was small $\left(\approx 200 \mathrm{~m}^{2}\right)$ and shallow $(\approx 1 \mathrm{~m})$.

Planktonic protist abundance and biomass were monitored over one year (12 sequestration cycles between February 1998 and February 1999), by weekly water samples. The first samples were taken two days after the pond's water was replaced to decrease the turbidity levels. Coastal water was channelled into the pond at high spring tides. Sea water 
was held in the pond for 3 to 4 weeks, resulting in progressive modifications in the ecological conditions of these semi-closed systems. At the end of the sequestration period, the pond was emptied at ebb tide and filled again with new water during the following high tide.

Physical parameters

Hydrological data were recorded by the Aanderaa data logger using sensors (thermometer and conductivity meter). The hydrological sensors were cleaned every $30 \mathrm{~min}$. The data were transferred every month via a portable computer to a magnetic disk in ASCII format.

\section{Experimental procedure}

Preliminary tests were performed to define an accurate sampling strategy for the pond's water column in order to estimate average values of microbiota abundance over its entire surface: the pond was divided into 12 squares ( $3 \mathrm{~m}$ wide) and 1 sub-surface water sample was taken from each square at each sampling date. These 12 samples were collected with a $2.5 \mathrm{~L}$ "Van Doorn" bottle (Wildco) and $500 \mathrm{ml}$ from each sample was mixed in a single, opaque carboy and quickly taken to the laboratory. The final $6 \mathrm{~L}$ sample was assumed to represent a mean spatial estimate of water column parameters within the pond and sampling date.

To estimate the production of planktonic protists in summer, pond water was collected in June 1999 using the sampling method described above.

\section{Taxonomy and enumeration of protist communities}

Taxonomic determination of protists present in the pond was done in accordance with systematic literature [26, 34, 37, 39, 43, 59].

For microphytoplanktonic cells (diatoms and dinoflagellates), a $20 \mathrm{~mL}$ triplicate aliquot from the $6 \mathrm{~L}$ pond water samples was fixed with formaldehyde (final concentration $1 \%)$ and stained with alkaline lugol. Microphytoplanktonic cells were counted in Utermöhl settling chambers (Hydro-Bios combined plate chambers) under an inverted microscope. The cell sizes (length and width) were measured on at least 100 cells through a calibrated ocular micrometer. From cell size measurements, the mean cell volume of each taxon was calculated by equating the shape to standard geometric configurations. The cell volume was converted into carbon units, using a theoretical carbon/volume ratio of $0.14 \mathrm{pg}$ Carbon (C) $\mu^{-3}$ [42].

For nanoplanktonic and microzooplanktonic cells: $40 \mathrm{~mL}$ and $100 \mathrm{~mL}$ triplicate aliquots of the $6 \mathrm{~L}$ sample of pond water were fixed, stained and enumerated according to methods described by Haas [20], Caron [6] and Sherr et al. [54] as modified by Dupuy et al. [11]. From replicate cell size measurements of all protists, the mean cell volume of each group was calculated as above for at least 100 cells. The cell volume was converted into carbon units, using a theoretical carbon/volume ratio of $0.14 \mathrm{pg}$ Carbon (C) $\mu^{-3}$ for nanoplankton (nanoflagellates) and $0.17 \mathrm{pg} \mathrm{C} \mathrm{m}^{-3}$ for microzooplankton (ciliates), ([42] corrected for glutaraldehyde fixative, according to Leakey et al. [31]).

\section{Measurement of growth rates and productions of planktonic protists}

Production rates were estimated for the summer period from the growth rates and biomass measured for each group.

To estimate diatom, dinoflagellate and ciliate growth rate in June 1999, organisms were fractionated by gravity filtration and reverse flow through nylon screens according to [15] and [16]. To remove different size classes of predators, $<145 \mu \mathrm{m}$ filtering removed copepods in water containing bacteria, nanoflagellates, diatoms, ciliates and dinoflagellates, $<45 \mu \mathrm{m}$ filtering removed large ciliates and diatoms in water containing bacteria, nanoflagellates, diatoms, ciliates and dinoflagellates. Non-fractionated seawater samples (entire population) were also incubated. Each size fraction was then transferred into 3 
polycarbonate bottles of $1 \mathrm{~L}$ in volume, closed at one end by a dialysis membrane (Spectra/Por, 2, 12000 to 14000 Daltons). The bottles were incubated in situ in the subsurface water for $24 \mathrm{~h}$. The abundance of each protist group was determined at the beginning and end of incubation.

The nanoflagellate growth rate was estimated using the dilution method [29] modified by [30]. One part of the water sample was filtered through a $1 \mu \mathrm{m}$ (Nuclepore) membrane. This filtered water, containing only bacteria, was then added to the unfiltered seawater: dilutions from 1 to $20 \%$. Two controls were taken: one with filtered seawater and the other one with unfiltered water. The dilution and controls were transferred into 3 one liter polycarbonate bottles, closed as above. Nanoflagellate abundance was determined at the beginning and end of incubation.

\section{Results}

Physical variables

Temperatures showed the expected seasonal pattern with lowest values $\left(2{ }^{\circ} \mathrm{C}\right)$ in November 98 and highest values in August $98\left(25^{\circ} \mathrm{C}\right)$ (Fig. 1A). The annual mean was $15.2{ }^{\circ} \mathrm{C}$.

Salinity of the coastal pond waters varied with the season. The maximum occurred at the beginning of September 98 (38.2) and the minimum in April 98 with 25.4 (Fig. 1B). The annual mean was 31 .

$\mathbf{A}$

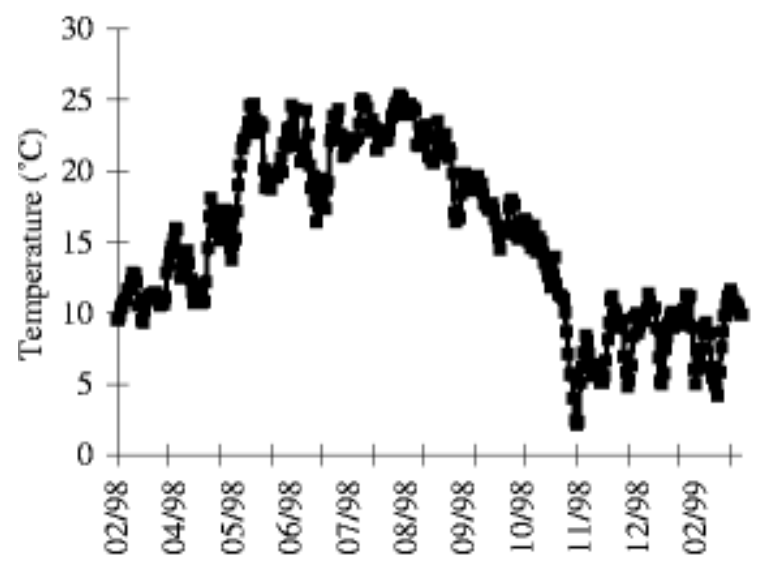

B

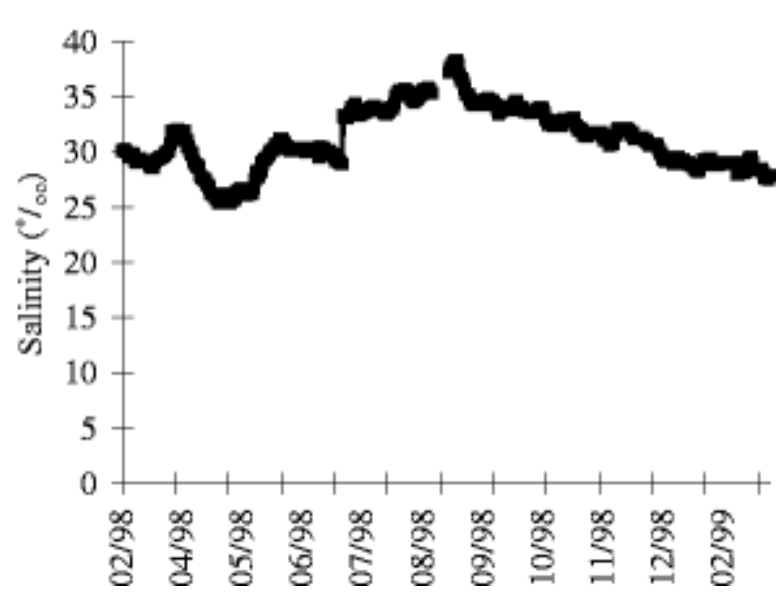

Figure 1. Seasonal variations in water temperature (A) and salinity (B) at column water between February 1998 and February 1999.

Diversity and standing stocks of protists

The annual cycle was divided into 2 periods, a winter period (from September to March) and a summer period (from April to August).

\section{Diatoms}

A total of 22 diatom taxa belonging to 2 orders of diatoms (centric and pennate diatoms, Table 1) was recorded in the Atlantic coastal pond during the sampling period, ranging in size from 11 to $125 \mu \mathrm{m}$ in length. Diatoms were put into 5 suborders (Table 1), all of which were identified to genus and a further 2 to species level. 
Table 1. Taxonomic composition, sizes, biovolumes of diatoms in the Atlantic coastal pond between February 1998 and February 1999. Classification according to Sournia [59].

The maximum number of taxa found during the one-year study was 10 in July (data not shown). The suborder of Naviculiineae (especially Cylindrotheca sp.) was mainly dominant throughout the follow-up in terms of abundance (63\% of diatom abundance) and biomass (65\% of diatom biomass) (Figs. 2A and 2B). Exceptionally, blooms of Coscinodiscineae (especially Skeletonema costatum) appeared in February, October and December 98 and in January 99. The suborder of Biddulphiineae (especially Cerataulina sp.) was seen in summer and at the beginning of autumn: in that period, they represented on average $78 \%$ of the population's abundance and $86 \%$ of the population's biomass of diatoms. 
A

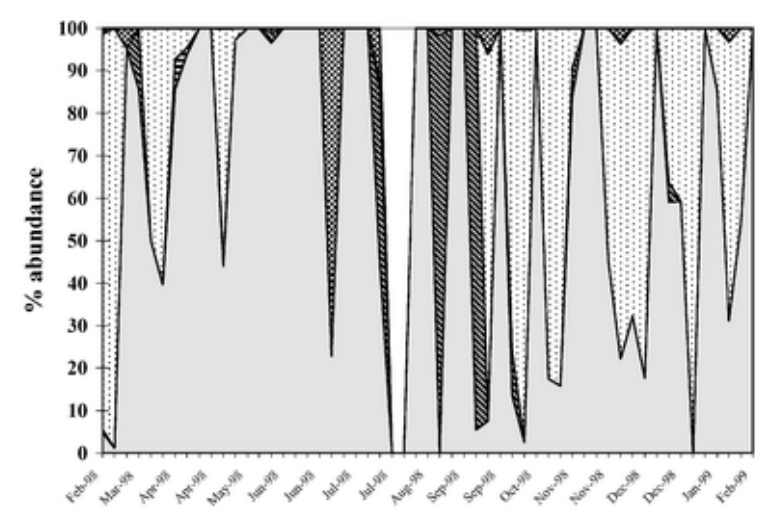

$\mathrm{B}$

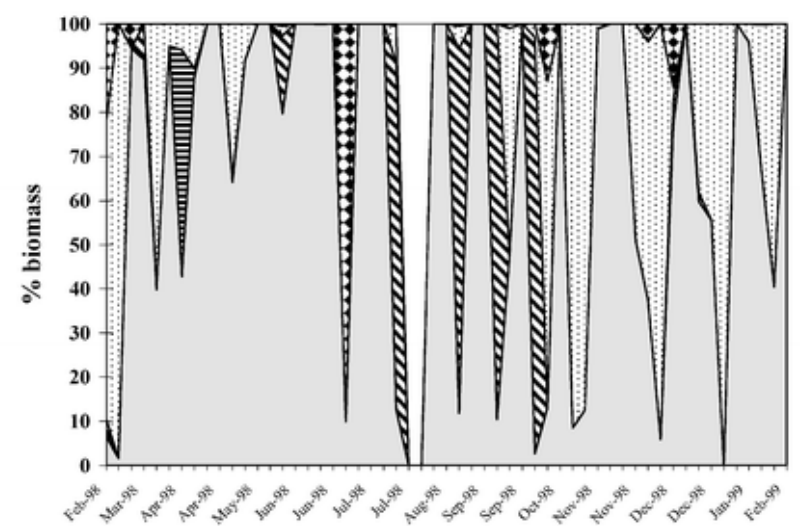

$\square \%$ Naviculiineae 目\% Fragilariineae $\mathbf{\Delta} \%$ Biddulphiineae $⿴$ \% Coscinodiscineae Rhizosoleniineae

Figure 2. Diatom abundance and biomass in Atlantic coastal pond waters between February 98 and February 99: (A) mean percentage abundance of diatom groups (B) mean percentage biomass of diatom groups. Breaks in curves correspond to 12 sequestration cycles. The first point of cycle is the first sampling 2 days after the arrival of the water and the last point of cycle is the end of the sequestration period.

Diatoms exhibited some degree of seasonal variability in population abundance and biomass: abundance was higher in spring $\left(1100 \times 10^{4}\right.$ cells $\mathrm{L}^{-1}$ in May) even though the biomass was $300 \mu \mathrm{g} \mathrm{C} \mathrm{L}^{-1}$ at the same period (Figs. 2C and 2D). The individual biovolumes of diatoms fluctuated greatly (Table 1). As a consequence of these fluctuations in biovolumes, and thus in biomass, taxa did not tend to reflect variations in abundance: on $29^{\text {th }}$ September, diatom abundance was low, $6.6 \times 10^{4}$ cells $\mathrm{L}^{-1}$ and biomass was maximal, $514 \mu \mathrm{g} \mathrm{C} \mathrm{L}^{-1}$ due to a moderate bloom of Amphora sp. (Naviculiineae) with high biovolume (318.2 x 10 $\mathrm{\mu m}^{3}$ ). In winter, abundance and biomass were lower (1600 cells $\mathrm{L}^{-1}$ and $0.2 \mu \mathrm{g} \mathrm{C} \mathrm{L}^{-1}$, in January 99). The mean abundance and biomass of diatoms were $1.2 \times 10^{6}$ cells $\mathrm{L}^{-1}$ and $39 \mu \mathrm{g} \mathrm{C} \mathrm{\textrm {L } ^ { - 1 }}$ respectively in the summer period (from April to August), and $6.2 \times 10^{4}$ cells L $^{-1}$ and $27 \mu \mathrm{g} \mathrm{C}$ $\mathrm{L}^{-1}$ respectively in the winter period (from September to March).

\section{Dinoflagellates}

A total of 14 dinoflagellate taxa was recorded in this Atlantic coastal pond's waters during the sampling period (Table 2) ranging in size from $23 \mu \mathrm{m}$ to $70 \mu \mathrm{m}$ length, 12 of which were identified to genus and a further 2 to species level (Table 2). 
Table 2: Taxonomic composition, sizes, biovolumes of dinoflagellates in the Atlantic coastal pond between January 1998 and February 1999. Classification according to Sournia [59].

\begin{tabular}{|c|c|c|c|c|c|}
\hline Order & Family & Genus & Species & $\begin{array}{l}\text { Cell length } \\
(\mu \mathrm{m})\end{array}$ & $\begin{array}{l}\text { Cell volume } \\
\left(\mathrm{x} 10^{3} \mu^{3}\right)\end{array}$ \\
\hline \multirow[t]{8}{*}{ Peridiniales } & & unidentified & & 24 & 15.1 \\
\hline & & unidentified & & 30 & 9.5 \\
\hline & Peridiniaceae & & & & \\
\hline & & Scripsiella & spp. & 29 & 8.4 \\
\hline & & Protoperidinium & spp. & 27 & 5.3 \\
\hline & & Minuscula & sp. & 15 & 1.7 \\
\hline & Gonyaulacaceae & & & & \\
\hline & & Amphidoma & sp. & 23 & 1.8 \\
\hline \multicolumn{6}{|c|}{ Gymnodiniales Gymnodiniaceae } \\
\hline & & Cochlodinium & spp. & 46 & 12.6 \\
\hline & & Amphidinium & spp. & 19 & 1.3 \\
\hline & & Gyrodinium & spp. & 40 & 7.6 \\
\hline & & Gymnodinium & spp. & 25 & 1 \\
\hline & & Gymnodinium & splendens & 70 & 55.6 \\
\hline \multicolumn{6}{|c|}{ Prorocentrales Prorocentraceae } \\
\hline & & Prorocentrum & spp. & 35 & 11.2 \\
\hline \multirow[t]{2}{*}{ Dinophysiale } & Dinophysiaceae & & & & \\
\hline & & Dinophysis & spp. & 51 & 17 \\
\hline \multirow[t]{2}{*}{ Ebriales } & Chrysophyceae & & & & \\
\hline & & Ebria & tripartita & 32 & 5.2 \\
\hline
\end{tabular}

The maximum number of taxa found together was 9 in July, August, September and October (data not shown). The minimum was 1 taxon in March, April and May. The Peridiniales (especially Scripsiella sp.) dominated the dinoflagellate community throughout the year in terms of abundance (69 \% of abundance) and biomass (66 \% of biomass): (Figs. 3A and 3B). Prorocentales appeared during spring (in April and May, $100 \%$ of abundance and biomass) and in July (98 \% of abundance and biomass). The order of Gymnodiniales was hardly present, except at the end of July and in August, where Gymnodinium splendens represented on average $43 \%$ of dinoflagellate abundance and $91 \%$ of dinoflagellate biomass (Figs. 3A and 3B). 

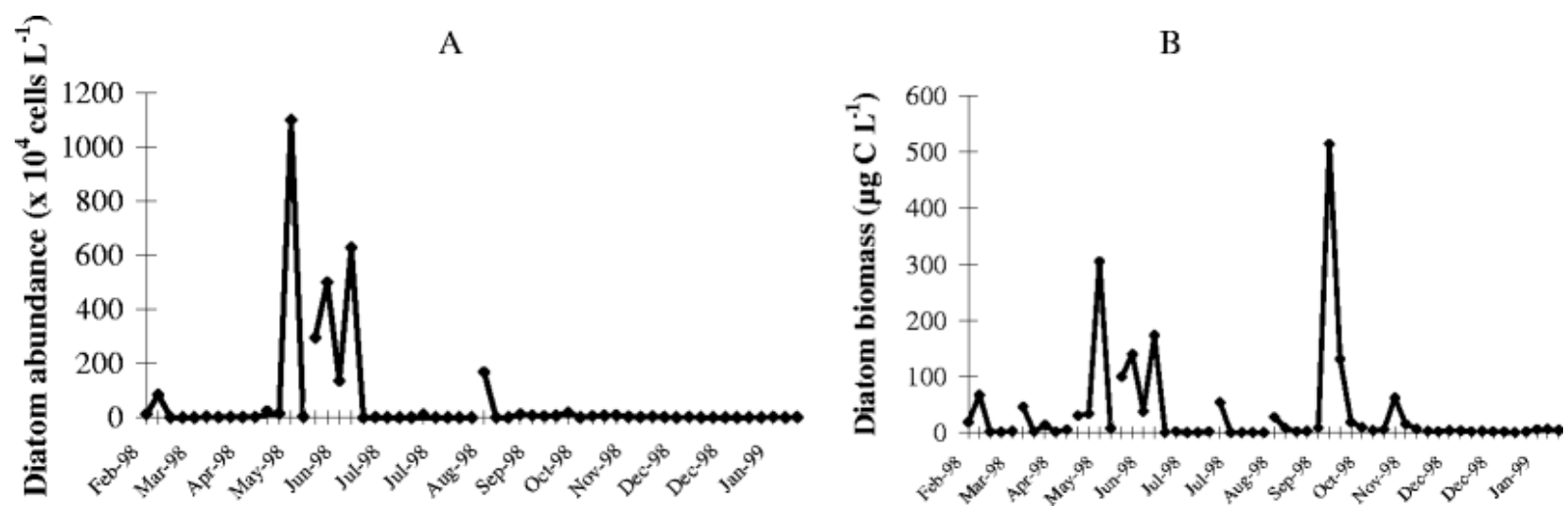

Figure 3 Diatom abundance and biomass in Atlantic coastal pond waters between February 98 and February 99: (A) mean abundance and (B) mean biomass of diatoms. Breaks in curves correspond to 12 sequestration cycles. The first point of cycle is the first sampling 2 days after the arrival of the water and the last point of cycle is the end of the sequestration period.

Dinoflagellates exhibited real seasonal variability in population abundance and biomass. They were widely present during the summer (Figs. 3C and 3D) and remained scarce during the rest of the year. Maximum abundance and biomass were found in July $(2.6 \mathrm{x}$ $10^{6}$ cells $\mathrm{L}^{-1}$ and $2054 \mu \mathrm{g} \mathrm{C} \mathrm{L}^{-1}$ ). The mean abundance and biomass of dinoflagellates were $2.4 \times 10^{5}$ cells $\mathrm{L}^{-1}$ and $286 \mu \mathrm{g} \mathrm{C} \mathrm{\textrm {L } ^ { - 1 }}$ respectively in summer and $3.8 \times 10^{4}$ cells $\mathrm{L}^{-1}$ and $11 \mu \mathrm{g}$ $\mathrm{C} \mathrm{L}^{-1}$ respectively in the winter period.

\section{Euglenophyceae}

The euglenophyceae were represented exclusively by the order of Eutrepsiales (Table 2). They often appeared during the one-year study (data not shown) but brought little carbon (maximal value of $5.6 \mu \mathrm{g} \mathrm{C} \mathrm{L}^{-1}$ in February and September and on average $0.5 \mu \mathrm{g} \mathrm{C} \mathrm{L}^{-1}$ ).

\section{Nanoflagellates}

The nanoflagellate enumeration method used, with a black Nuclepore filter, prevented their taxonomic determination. Only the size and the cell outlines of nanoflagellates were estimated. Moreover, the method allowed us to distinguish pigmented nanoflagellates from colourless ones (Caron 1983).

A total of 27 different nanoflagellate forms was recorded in the pond waters during the sampling period, ranging in size from 3 to $19 \mu \mathrm{m}$ in length. The maximum number of different nanoflagellates found together was 23 in July and 24 in September (data not shown). The minimum was 5 different nanoflagellate forms in March.

During the one-year study, pigmented nanoflagellates dominated the population (80 to $90 \%$ of population abundance and biomass, Figs. 4A and 4B) except in April where colourless nanoflagellates constituted $60 \%$ of their abundance and $50 \%$ of their biomass in June, July and January 99. 
A

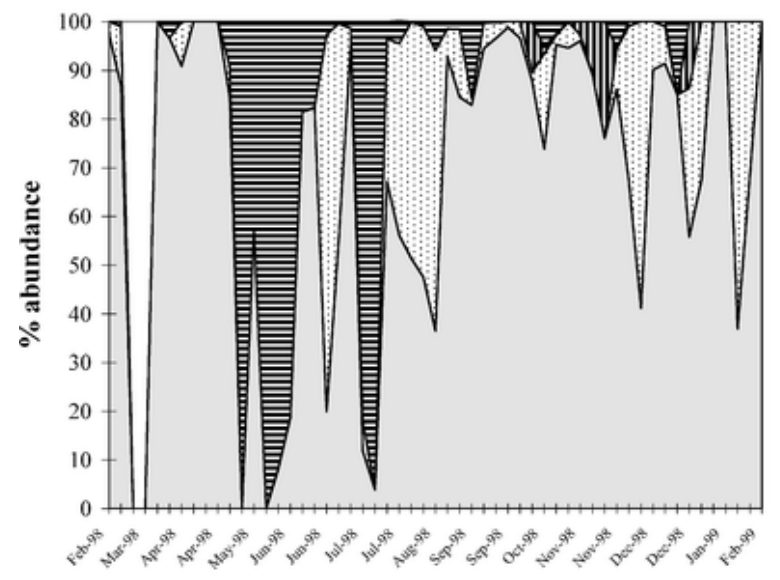

B

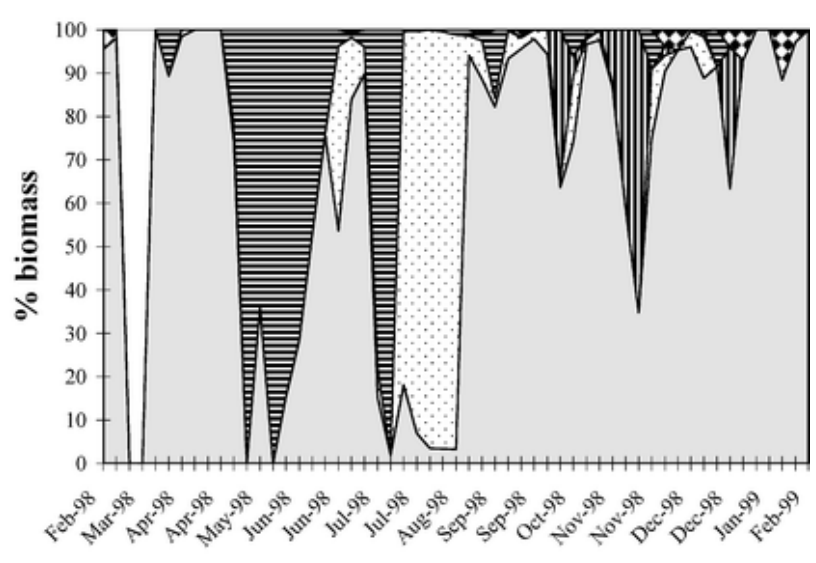

$\square \%$ Peridiniales $\quad$ \% Gymnodiniales 血\% Ebriales 目\% Prorocentrales $\%$ other dinoflagellates

Figure 4 Dinoflagellate abundance and biomass in coastal pond waters between February 98 and February 99: (A) mean abundance and (B) mean biomass of dinoflagellate groups (B) mean perecentage biomass of dinoflagellate groups.

Nanoflagellate abundance and biomass varied according to the season (Figs. 4C and 4D): the high values were found during spring (2500 x $10^{5}$ cells $\mathrm{l}^{-1}$ and $1700 \mu \mathrm{g} \mathrm{C}^{-1}$ ) and summer (3.2 x $10^{8}$ cells $\mathrm{L}^{-1}$ and $\left.1650 \mu \mathrm{g} \mathrm{C} \mathrm{L}^{-1}\right)$. During the winter, nanoflagellate abundance and biomass were generally low, except in December, where a moderate bloom of

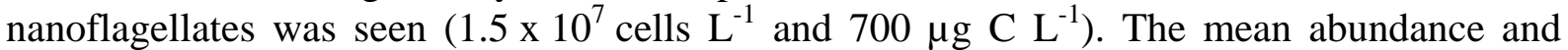
biomass of nanoflagellates were $7.7 \times 10^{7}$ cells $\mathrm{L}^{-1}$ and $681 \mu \mathrm{g} \mathrm{C} \mathrm{\textrm {L } ^ { - 1 }}$ respectively in the

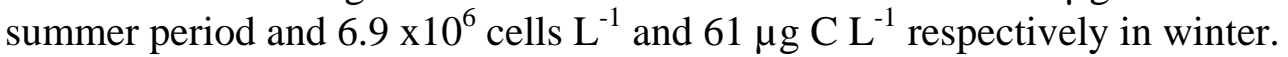

\section{Ciliates}

A total of 21 ciliate taxa was recorded in the Atlantic coastal pond waters during the one-year study, 16 of which were identified to genus and a further 3 to species level (Table 3 ). 
Table 3: Taxonomic composition, sizes, biovolumes of the ciliate community in the Atlantic coastal pond between January 1998 and February 1999. Classification according to Lee et al. [34].

\begin{tabular}{|c|c|c|c|c|c|c|c|}
\hline Sub-class & Order & Suborder & Family & Genus & Species & $\begin{array}{c}\text { length } \\
(\mu \mathrm{m})\end{array}$ & $\begin{array}{l}\text { Cell volume } \\
\left(\mathrm{x} 10^{3} \mu \mathrm{m}^{3}\right)\end{array}$ \\
\hline \multicolumn{8}{|l|}{ Choreotrichia } \\
\hline & Choreotrichida & Tintinnina & Codonellidae & & & & \\
\hline & & & & Tintinnopsis & sp. 1 & 53 & 38 \\
\hline & & & & Tintinnopsis & sp. 2 & 60 & 18.3 \\
\hline & & & & Tintinnopsis & sp. 3 & 97 & 136.4 \\
\hline & & & & unidentified & & 46 & 207.4 \\
\hline & & & Codonellopsidae & & & & \\
\hline & & & & Stenosemella & sp. & 38 & 15.9 \\
\hline & & & Tintinnidae & & & & \\
\hline & & & & Eutintinnus & sp. & 110 & 54 \\
\hline & & Strobilidiina & Strobilidiidae & & & & \\
\hline & & & & Lohmaniella & sp. & 37 & 33.4 \\
\hline & & & & Strobilidium & sp. & 40 & 14.6 \\
\hline & Oligotrichida & & Strombidiidae & & & & \\
\hline & & & & Strombidium & sp. & 46 & 24.9 \\
\hline & & & & Strombidium & conicum & 68 & 47.9 \\
\hline & & & Halteriidae & & & & \\
\hline & & & & Halteria & sp. & 34 & 8.6 \\
\hline & Haptorida & & Mesodiniidae & & & & \\
\hline & & & & Askenasia & sp. & 49 & 96 \\
\hline & & & & Mesodinium & sp. & 26 & 5.7 \\
\hline & & & & Mesodinium & pulex & 18 & 1.3 \\
\hline & & & & Mesodinium & rubrum & 38 & 9.3 \\
\hline & & & Didinnidae & & & & \\
\hline & & & & Didinium & sp. & 49 & 37 \\
\hline \multicolumn{8}{|l|}{ Hymenostomatia } \\
\hline & Scuticociliatida & unidentified & & & & 44 & 27.9 \\
\hline & & Phylasterina & Uronematidae & & & & \\
\hline & & & & Uronema & sp. & 34 & 3.7 \\
\hline \multicolumn{8}{|l|}{ Hypotrichia } \\
\hline & unidentified & & & & & 44 & 16 \\
\hline & Stichotrichia & Sporadotrichina & Oxytrichidae & & & & \\
\hline & & & & unidentified & & 81 & 17.3 \\
\hline \multicolumn{8}{|l|}{ Karyorelictea } \\
\hline & Protostomatida & unidentified & & & & 15 & 0.7 \\
\hline Unidentified aloricate ciliate & & & & & & 93 & 129.9 \\
\hline
\end{tabular}

The length of ciliates ranged from 15 to $110 \mu \mathrm{m}$. The greatest number of taxa was 14 in February (data not shown). The minimum was 2 taxa in July and August. Ciliates were members of Choreotrichia with the suborder of Tintinnina (loricate cells) and aloricate forms such as Oligotrichida (Table 3). Aloricate ciliates dominated the population abundance and biomass during most months, comprising up to $100 \%$ of the abundance and biomass (Figs. 5A and 5B). In aloricate ciliates, Oligotrichids (especially Strombidium sp.) were the commonest taxonomic group (Figs. 5A and 5B). Tintinnids (loricate ciliates) were the second most present group, except in June, July and all autumn, when they represented $70 \%$ of population abundance and $74 \%$ of population biomass (Figs. 5A and 5B). Haptorida were present during the one-year study with peaks in April (95\% of population abundance and biomass), June and September ( $\approx 100 \%$ of population abundance and biomass in September). The order of Strobilidiina remained scarce, except in December, when they represented 50\% of population biomass. The sub-classes of Hypotrichs, Scuticociliatida and Oxytrichia, more characteristic of benthic environments, were only present on a few occasions. 

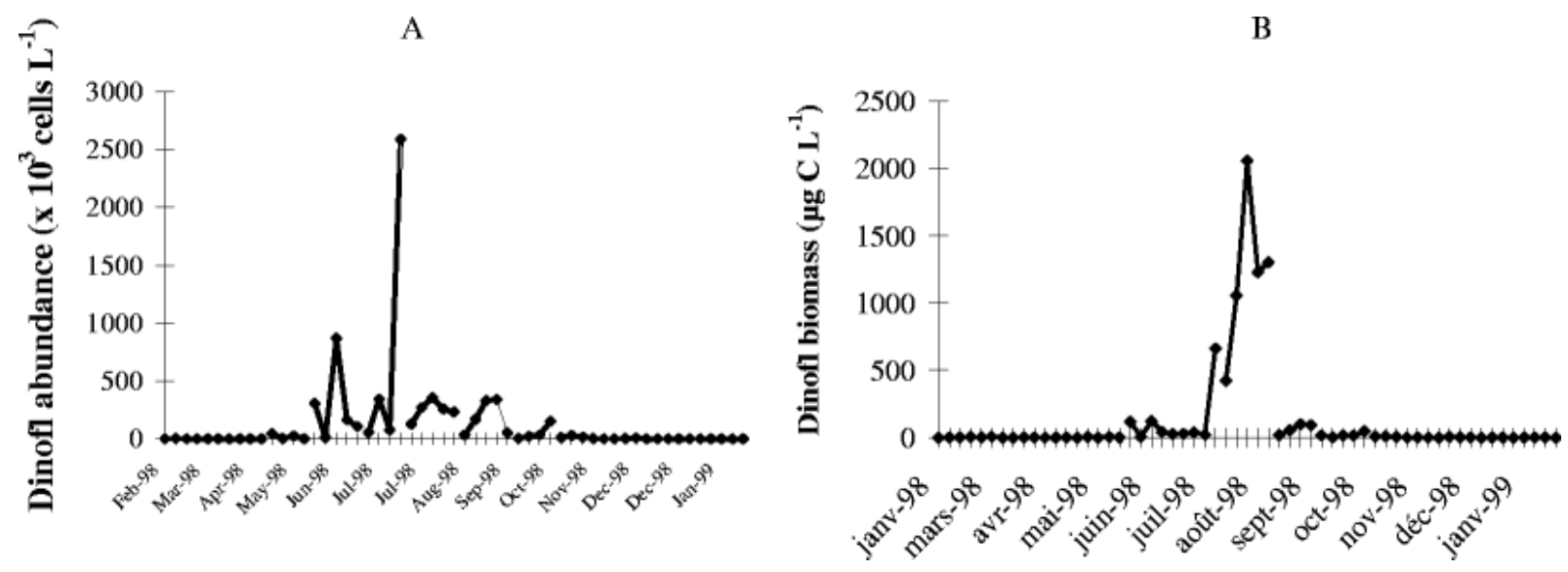

Figure 5 Dinoflagellate abundance and biomass in coastal pond waters between February 98 and February 99: (A) mean abundance and (B) mean biomass of dinoflagellates. Breaks in curves correspond to 12 sequestration cycles. The first point of cycle is the first sampling 2 days after the arrival of the seawater and the last point cycle is the end of the sequestrastion period. Dinofl = dinoflagellates

Ciliates exhibited some degree of seasonal variability in population abundance and biomass. The biomass of ciliates tended to reflect variations in abundance. Ciliates were present during the one-year study (Figs. 5C and 5D) with peaks in spring, summer (in July, $1.45 \times 10^{5}$ cells $\mathrm{L}^{-1}$ and $142 \mu \mathrm{g} \mathrm{C} \mathrm{L}^{-1}$ ) and autumn. During the winter, ciliates were not often present or were absent in February, July and November 98 and January 99. The mean abundance and biomass of ciliates were $32 \times 10^{3}$ cells $\mathrm{L}^{-1}$ and $27 \mu \mathrm{g} \mathrm{C} \mathrm{L}{ }^{-1}$ respectively in summer period and $13 \times 10^{3}$ cells $\mathrm{L}^{-1}$ and $13 \mu \mathrm{g} \mathrm{C} \mathrm{L}^{-1}$ respectively in winter period.

The available biomass of major protists present in coastal pond waters was assessed (Fig. 6). In the summer period (from April to August), nanoflagellates were predominant in the water column $\left(681 \mu \mathrm{g} \mathrm{C} \mathrm{L}^{-1}\right)$. The estimated biomass of other microbes was lower, with

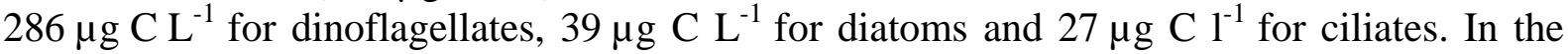
winter period (from September to March), nanoflagellates were always most predominant in

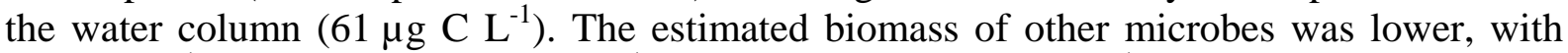

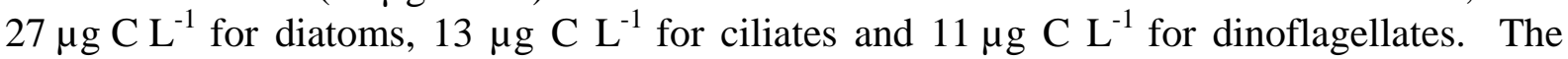
biomass of protist carbon available in the pond waters was 9 times lower in winter than in the summer period. 
A

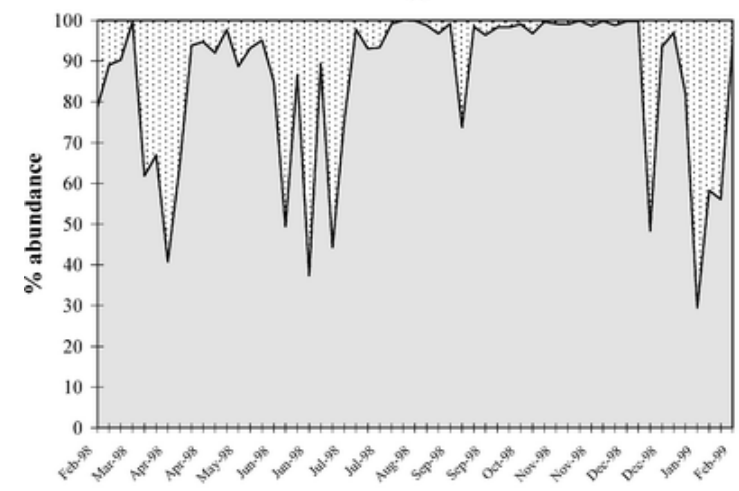

$\square \% \mathrm{ANF}$

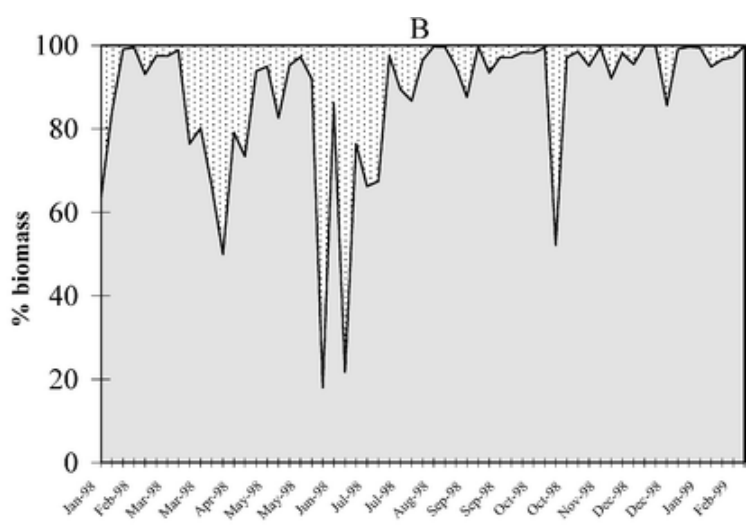

웅 HNF

Figure 6 Nanoflagellates abundance and biomass in coastal pond waters between February 98 and February 99: (A) mean percentage abundance of nanoflagellate groups (B) mean percentage biomass of nanoflagellate groups. ANF: Autotrophic nanoflagellates, HNF: Heterotrophic nanoflagellates.
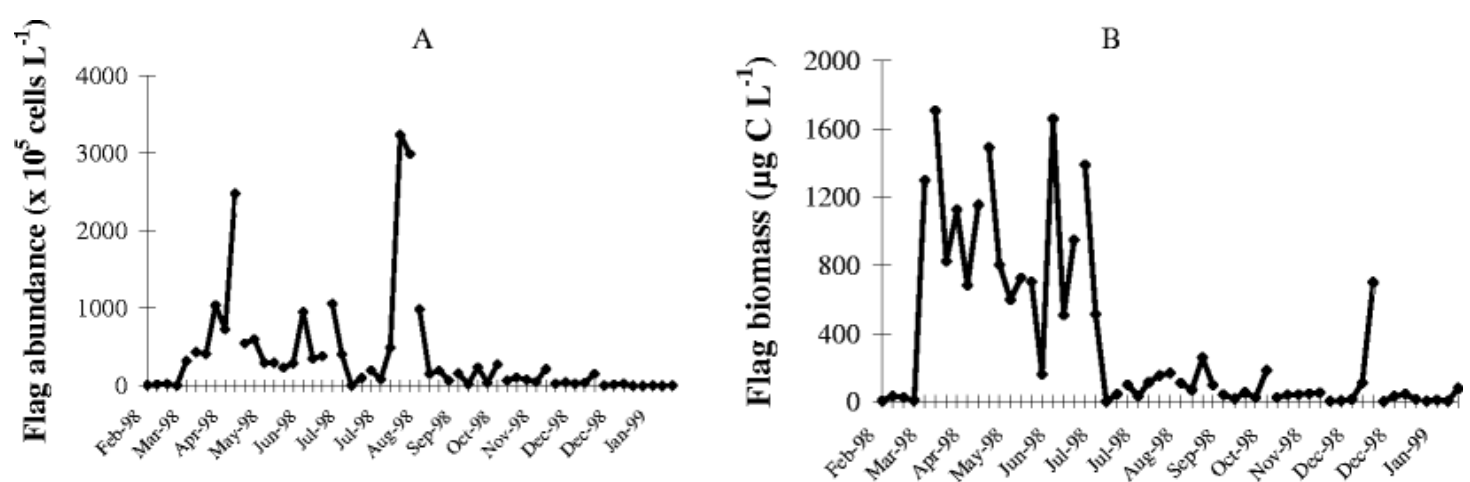

Figure 7 Nanoflagellates abundance and biomass in coastal pond waters between February 98 and February 99: (A) mean abundance and (B) mean biomass of nanoflagellates. Breaks in curves corresponds to 12 sequestration cycles. The first point of cycle is the first sampling 2 days after the arrival of the seawater and the last point of cycle is the end of the sequestration period. Flag=nanoflagellates.

A

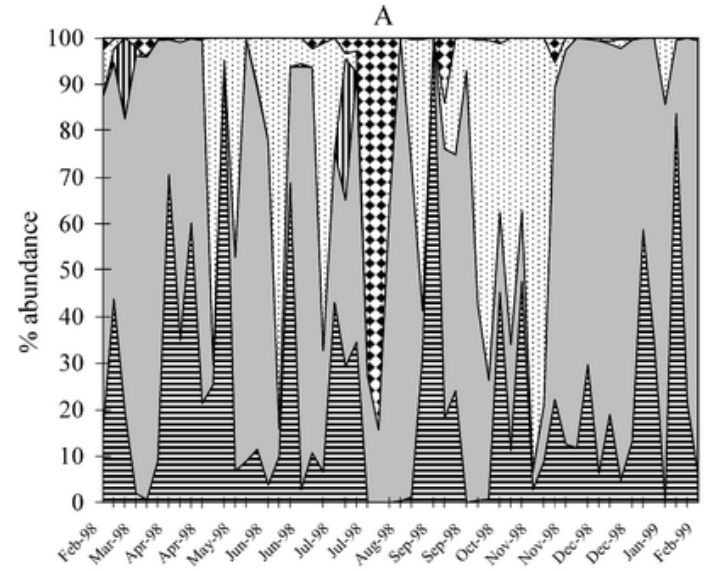

B

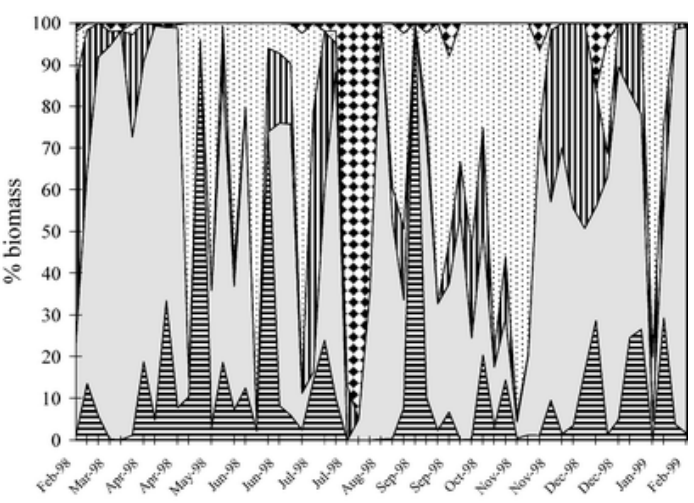

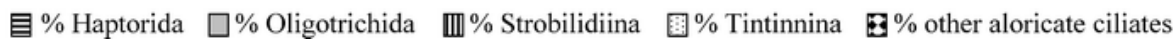

Figure 8 Ciliate abundance and biomass in coastal pond waters between February 98 and February 99: (A) mean percentage abundance of ciliate groups, (B) mean percentage biomass of ciliate groups. Breaks in curves correspond to 12 sequestration cycles. The first point of cycle is the first sampling 2 days after the arrival of the seawater and the last point of cycle is the end of the sequestration period. 

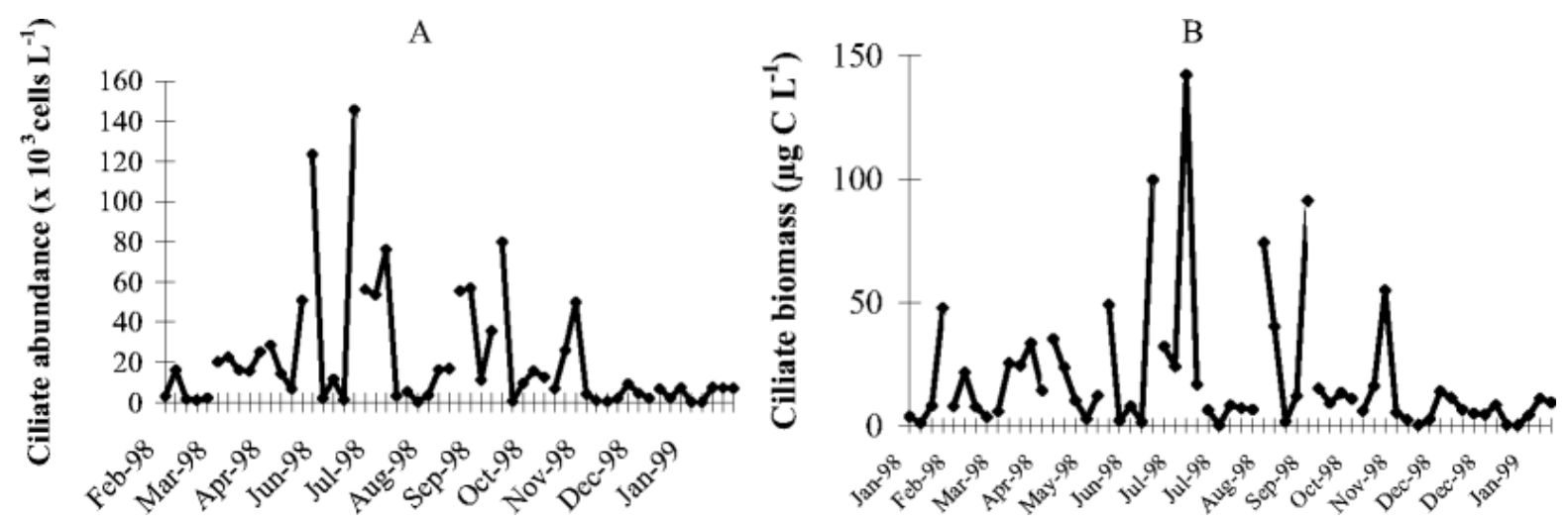

Figure 9 Ciliate abundance and biomass in coastal pond waters between February 98 and February 99: (A) mean abundance and (B) mean biomass of ciliates. Breaks in curves correspond to 12 sequestration cycles. The first point of cycle is the first sampling 2 days after the arrival of the seawater and the last point of cycle is the end of the sequestration period.

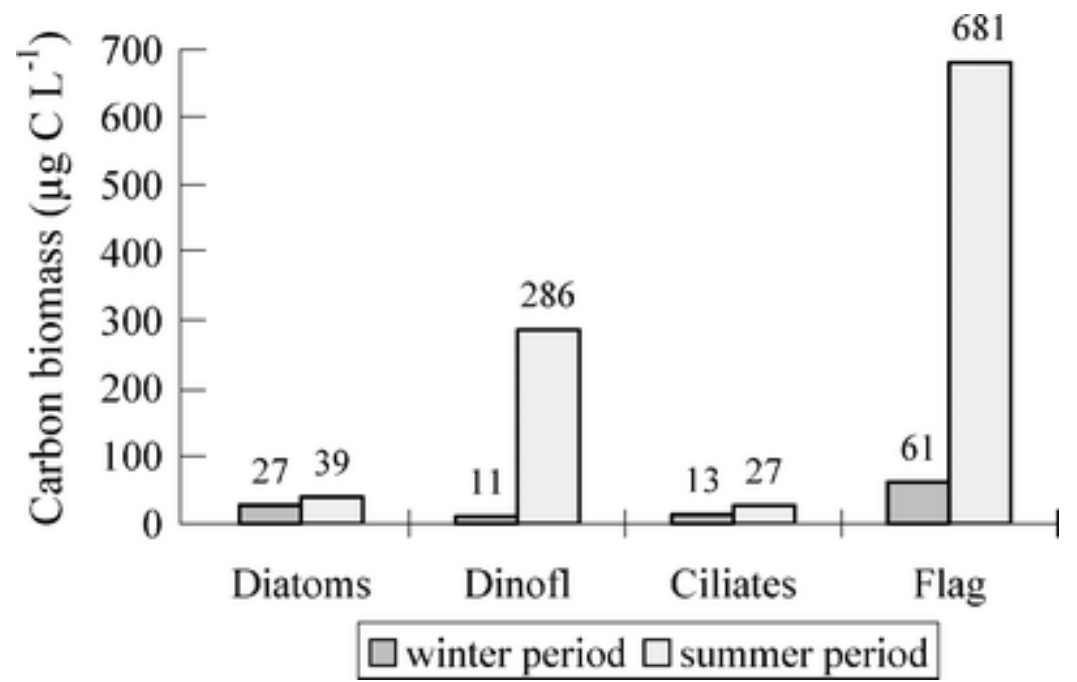

Figure 10 Mean biomass of major taxonomic groups in the column water pond between February 98 and February 99 at two different periods, in winter (from September to MArch) and in summer (from April to August). Donofl=dinoflagellates, Flag=nanoflagellates.

Estimation of growth rates and productions of various planktonic protist communities for the summer period

Growth rates varied from one taxonomic group to another (Table 4). Nanoflagellates exhibited the highest growth rate: $0.098 \mathrm{~h}^{-1}$ compared to $0.026 \mathrm{~h}^{-1}$ for ciliates, $0.07 \mathrm{~h}^{-1}$ for diatoms and $0.06 \mathrm{~h}^{-1}$ for dinoflagellates. The protist communities multiplied between 1 to 7 times per day in the coastal pond waters. 
Table 4: Growth rates $\left(\mathrm{h}^{-1}\right)$ and generation time (h) obtained for different groups during incubation experiments in the summer period. Estimated productions $\left(\mu \mathrm{C} \mathrm{L} \mathrm{L}^{-1}\right.$ day $\left.^{-1}\right)$ were calculated to multiply the biomass $\left(\mu \mathrm{g} \mathrm{C} \mathrm{L}^{-1}\right)$ of each group by this respective growth rate $\left(\mathrm{h}^{-1}\right)$.

\begin{tabular}{lcccc} 
& $\begin{array}{c}\text { Growth rate } \\
\left(\mathrm{h}^{-1}\right)\end{array}$ & $\begin{array}{c}\text { Generation time } \\
(\mathrm{h})\end{array}$ & $\begin{array}{c}\text { Biomass } \\
\left(\mu \mathrm{g} \mathrm{C} \mathrm{L}^{-1}\right)\end{array}$ & $\begin{array}{c}\text { Production } \\
\left(\mu \mathrm{C} \mathrm{C} \mathrm{L}^{-1} \mathrm{day}^{-1}\right)\end{array}$ \\
\hline Diatoms & 0.07 & 9.9 & 39 & 66 \\
Dinoflagellates & 0.06 & 11.6 & 286 & 412 \\
Ciliates & 0.026 & 26.7 & 27 & 17 \\
Flagellates & 0.098 & 7.1 & 681 & 1602 \\
\hline Sum & & & 1033 & 2096
\end{tabular}

In term of production, nanoflagellates showed the highest production in summer period with $1602 \mu \mathrm{g} \mathrm{C} \mathrm{L}{ }^{-1}$ day $^{-1}$ (Table 4) against $412 \mu \mathrm{g} \mathrm{C} \mathrm{L}^{-1}$ day $^{-1}$ for dinoflagellates,

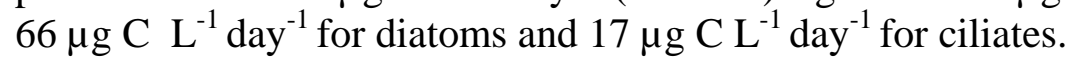

\section{Discussion}

Qualitative protist composition of the water column in the Atlantic coastal pond

The microphytoplanktonic cells present were mostly diatoms and dinoflagellates and the microzooplanktonic cells were ciliates. Nanoplanktonic cells were represented by pigmented and colourless nanoflagellates.

For diatoms, the suborder of Naviculiineae was mainly dominant (Fig. 2) with blooms of Skeletonema costatum (Coscinodoscineae) in spring and a bloom of Amphora sp. in autumn. Peridiniales dominated the dinoflagellates (Fig. 3). In the available published data on coastal ponds, similar qualitative composition and population dynamics of microphytoplankton were seen in the Bay of Bourgneuf [45, 47]. Nanoflagellates were dominated by pigmented cells (80 to $90 \%$ of the total nanoflagellate biomass) (Fig. 4). Crottereau [8] found a high fraction of chlorophyll a, which were cells less than $20 \mu \mathrm{m}$ in size, during annual monitoring (1996-1997) in the same coastal pond near la Rochelle. Ciliates belonging to the Choreotrichs sub-class were usually the predominant planktonic ciliates in most environments [5, 10, 48, 51, 52]. Oligotrichids were the commonest taxonomic group found during monitoring (Fig. 5).

Quantitative protist composition of the water column in coastal pond

Our estimations of planktonic diatom abundance throughout the year (Fig. 2) were within the abundance range found by Robert [47] (Table 5). Our biomass measurements were lower than in Chesapeake Bay [36].

Our dinoflagellate abundance was higher than in Buzzards Bay (Massachusetts) [40] (Table 5). A study made in the Antioche pertuis area (near La Rochelle on the French Atlantic coast) showed that the dinoflagellate biomass was $0.3 \mu \mathrm{g} \mathrm{C} \mathrm{L}^{-1}$ in January 98, a value similar to that in the pond $\left(0.59 \mu \mathrm{g} \mathrm{C} \mathrm{L}^{-1}\right)$. In February 98, the dinoflagellate biomass in the Antioche pertuis was higher than in the pond $\left(12.4 \mu \mathrm{g} \mathrm{C} \mathrm{L}^{-1}\right.$ in the pertuis versus $1.6 \mu \mathrm{g} \mathrm{C} \mathrm{L}^{-1}$ in the pond). This phenomenon could be due to the lower temperature in the pond in February 98 $\left(6.9^{\circ} \mathrm{C}\right.$, Fig. 1$)$, which did not allow the development of dinoflagellates, compared to a moderate temperature in open water. 
In this study, the abundance and biomass of nanoflagellates were higher than in the same coastal pond in April and July 96 (Robin, comm.pers.) (Table 5). In comparison with distant estuaries and bays, nanoflagellates were always higher than in the Saint-Lawrence estuary [35] and than at the surface in the summer period of Aarhus Bay (Danemark), [23].

Marine planktonic ciliates were recently shown to be abundant in Atlantic ponds: the compartment represented $63.5 \mu \mathrm{g} \mathrm{C} \mathrm{L}{ }^{-1}$ during June 1997 [11]. In the same Atlantic pond, from April to July 1996, Robin (com. pers.) found similar values, from 50 to $60 \mu \mathrm{g} \mathrm{C} \mathrm{L}^{-1}$. The ciliate biomass was higher than that observed for other coastal and estuarine localities: in Cobb Seamount [56], in the Saint-Lawrence estuary, [57] and in the Northern Arabian Sea [32] (Table 5). 
Table 5: Comparison of abundance (cells $\mathrm{L}^{-1}$ ) and biomass $\left(\mu \mathrm{g} \mathrm{C} \mathrm{L}^{-1}\right)$ with other Bays and Estuaries

\begin{tabular}{|c|c|c|c|}
\hline \multicolumn{4}{|l|}{ Groups } \\
\hline Diatoms & Abundance $\left(\mathrm{Cells} \mathrm{L}^{-1}\right)$ & Site & Authors \\
\hline & $1, \mathrm{E}+05$ & Bourgneuf bay & Robert (1983) \\
\hline & $6,3 \mathrm{E}+05$ & Atlantic coastal pond & Our study \\
\hline & Biomass $\left(\mu \mathrm{g} \mathrm{C} \mathrm{L}^{-1}\right)$ & Site & Authors \\
\hline & $200-500$ & Chesapeake bay & Malone \& Ducklow (1990) \\
\hline & 33 & Atlantic coastal pond & Our study \\
\hline \multirow[t]{3}{*}{ Dinoflagellates } & Abundance $\left(\right.$ Cells L $\left.^{-1}\right)$ & Site & Authors \\
\hline & $9,7 \mathrm{E}+03$ & Buzzards bay & Pierce \& Turner (1994) \\
\hline & $1,4 \mathrm{E}+05$ & Atlantic coastal pond & Our study \\
\hline \multirow[t]{7}{*}{ Nanoflagellates } & Abundance $\left(\right.$ Cells L $\left.^{-1}\right)$ & Site & Authors \\
\hline & $3,8 \mathrm{E}+06$ & Saint-Lawrence estuary & Lovejoy et al (1993) \\
\hline & $4,2 \mathrm{E}+07$ & Atlantic coastal pond & Our study \\
\hline & Biomass $\left(\mu \mathrm{g} \mathrm{C} \mathrm{L}^{-1}\right)$ & Site & Authors \\
\hline & 40 & Atlantic coastal pond & Robin, comm.pers. \\
\hline & 90 & Aarhus Bay & Havskum \& Riemann (1996) \\
\hline & 371 & Atlantic coastal pond & Our study \\
\hline \multirow[t]{5}{*}{ Ciliates } & Biomass $\left(\mu \mathrm{g} \mathrm{C} \mathrm{L} \mathrm{L}^{-1}\right)$ & Site & Authors \\
\hline & 0.4 to 14 & Cobb Seamount & Sime-Ngando et al (1992) \\
\hline & 0.23 to 51.6 & Saint-Lawrence estuary & Sime Ngando et al (1995) \\
\hline & 0.1 to 1.2 & Northern Arabian Sea & Leakey et al (1996) \\
\hline & 20 & Atlantic coastal pond & Our study \\
\hline
\end{tabular}

The study in the Antioche Pertuis area showed that in January 98, the ciliate biomass

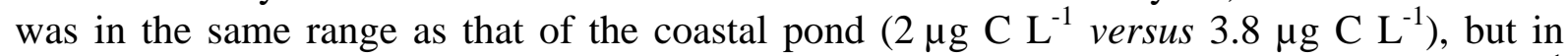
February 98, the biomass in open water was higher than in the semi-closed pond $\left(21 \mu \mathrm{g} \mathrm{C} \mathrm{L}^{-1}\right.$ versus $10.3 \mu \mathrm{g} \mathrm{C} \mathrm{L}^{-1}$ ). The same assessment, as already mentioned above for dinoflagellates, can also be reliable for ciliates: the low temperature (Fig. 1) limited the development of ciliates in the coastal pond.

To summarize, pigmented nanoflagellates were the primary resource available in the water column (60\% of the total protist biomass) (Fig. 6). The second carbon resource was that of dinoflagellates (28\% of the total protist biomass). Diatoms and ciliates represented supplementary carbon resources available in the water column. In the absence of published data on nano-microzooplankton in a coastal pond, we are the first to report, here, that pigmented nanoflagellates represent the highest food source available for higher trophic levels, such as oysters. Diatoms, considered as the principal food of oysters, represent only a complementary carbon resource in the Atlantic pond.

Production of microbiota in the water column in the coastal pond for summer period

Nanoflagellates dominated the planktonic protist production (76\% of total carbon protist production) in the pond (Table 4). Dinoflagellates represented the second highest yield 
in the coastal pond (20\% of total carbon protist production). Our results confirm the previous results reported by Robert [47] in a coastal pond. The ciliate production was the lowest (1\% of total carbon protist production), but the growth yield of this compartment was high (47 to $70 \%,[14,38,50,62]$. Therefore, the loss of energy is minimal at the moment of transfer from bacteria to the higher trophic level of ciliates.

During our monitoring, the system appeared to be more autotrophic than heterotrophic, since heterotrophic cells were less abundant and productive than autotrophic cells. However, mixotrophy was extensive in planktonic protists, under conditions of inorganic nutrient limitation [58]. In coastal marine environments, phytoflagellates may account for $>50 \%$ of the flagellate bacterivory in summer and somewhat less in winter [12, 21, 23]. For dinoflagellates, mixotrophy was also widespread [58]. It is estimated that approximately half of the known species of living dinoflagellates are obligate heterotrophs [18], and for most of them, the relative importance of photosynthesis, uptake of dissolved inorganic nutrients and feeding are all unknown [58]. Since in a semi-closed coastal pond, inorganic nutrients are quickly exhausted, planktonic pigmented cells dominate the carbon biomass and production and bacteria are numerous, we could believe that mixotrophy was apparently the significant trophic mode in the coastal pond. Previous studies over the same summer period showed that all bacterial production was grazed by higher trophic planktonic levels [8]. Thus the microbial food web appeared to be active in the coastal pond, channeling the energy from the pool of dissolved matter to higher trophic levels. In future studies, it will be important to obtain information about the mixotrophy of phytoflagellates and dinoflagellates and we will need to quantify the functional relationships between the phototrophy/phagotrophy of phytoflagellates and dinoflagellates.

Acknowledgements: We thank M. Bréret * for her technical assistance and A. Pastoureaud $*$ for her critical review of the manuscript. We thank Janet Heard Carnot for reviewing the English. This study was carried out with financial support from the Conseil Général de Charente-Maritime. 


\section{References}

1. Azam F, Fenchel T, Field JG, Gray JS, Meyer-Reil LA, Thingstad F (1983) The ecological role of water-column microbes in the sea. Mar Ecol Prog Ser 10 :257-263

2. Barillé L, Prou J, Héral M, Bougrier S (1993) No influence of food quality, but rationdependent retention efficiencies in the Japanese oyster Crassostrea gigas. J Exp Mar Biol Ecol 171:91-106

2. Berk SG, Brownlee DC, Heinle DR, Kling, Colwell RR (1977) Ciliates as a food source for marine planktonic copepods. Microb Ecol 4: 27-40

3. Blanchard G, Sauriau PG, Cariou-Le Gall V, Gouleau D, Garet MJ, Olivier F (1997) Kinetics of tidal resuspension of microbiota: testing the effects of sediment cohesiveness and bioturbation using flume experiments. Mar Ecol Prog Ser 151:17-25

5. Carlough LA, Meyer JL (1989) Protozoans in two southeastern blackwater rivers and their importance to trophic transfer. Limnol Oceanogr 34: 163-177

6. Caron DA (1983) Technique for enumeration of heterotrophic and phototrophic nanoplankton, using epifluorescence microscopy, and comparison with other procedures. Appl Environ Microbiol 46: 491-498

7. Chrétiennot-Dinet MJ, Guillocheau N (1987) Etude des diatomées d'écosystèmes marins côtiers. Observations nouvelles en microscopie électronique. Cah Bio Mar 28: 271-279

8. Crottereau C (1999) Dynamique des populations bactériennes dans un marais maritime atlantique: contribution des activités ectoproteolytique et d'uptake des acides aminés à la production bactérienne. PhD Océanologie: Université d'Aix-Marseille II, 216p

9. Delmas D, Frikha MG, Reymond H, Linley EAS, Collos Y (1992) Long term microbial community dynamics in a coastal marine pond. Mar Microb Food Webs 6: 39-54

10. Dolan JR (1991) Guilds of ciliate microzooplankton in the Chesapeake Bay. Estuarine Coastal and Shelf Science 33: 137-152

11. Dupuy C, Le Gall S, Hartmann HJ, Bréret M (1999) Retention of ciliates and flagellates by the oyster Crassostrea gigas in French Atlantic coastal ponds: protists as a trophic link between bacterioplankton and benthic suspension-feeders. Mar Ecol Prog Ser 177: 165175

12. Epstein SS, Shiaris MP (1992) Size-selective grazing of coastal bacterioplankton by natural assemblages of pigmented flagellates, colorless flagellates, and ciliates. Microb Ecol 23: 211-225

13. Fenchel T (1988) Ecology of protozoa - the biology of free-living phagotrophic protists. Berlin:Springer-Verlag

14. Fenchel T, Jonsson PR (1988) The fonctionnal biology of Strombidium sulcatum, a marine oligotrich ciliate (Ciliophora, Oligotrichina). Mar Ecol Prog Ser 48: 1-15

15. Ferrier-Pagès C, Rassoulzadegan F (1994) Seasonal impact of the microzooplankton on pico- and nanoplankton growth rates in the northwest Mediterranean Sea. Mar Ecol Prog Ser 108: 283-294

16. Ferrier-Pagès C, Gattuso JP (1998) Biomass, production and grazing rates of pico- and nanoplankton in coral reef waters (Miyako Island, Japan). Microb Ecol 35: 46-57

17. Frikha MG, Linley EAS, Delmas D (1987) Evolution annuelle et saisonnière de la microbiomasse d'une claire à huîtres : importance des populations bactérioplanctoniques. Oceanis 13: 433-447

18. Gaines G, Elbrächter M (1987) Chapter 6, heterotrophic nutrition. In: Taylor FJR (ed.), The Biology of Dinoflagellates. Blackwell Scientific Publications, Oxford: 224-268

19. Gifford DJ, Dagg MJ (1991) The microzooplankton-mesozooplankton link: consumption of planktonic protozoa by the calanoid copepods Acartia clausi Dana and Neocalanus plumchrus Murukawa. Mar Microb Food Webs 5: 161-177 
20. Haas LW (1982) Improved epifluorescence microscopy for observing planktonic microorganisms. Ann Inst Océanogr 58: 261-266

21. Hall JA, Barrett DP, James MR (1993) The importance of phytoflagellate, heterotrophic flagellate and ciliate grazing on bacteria and picophytoplankton sized prey in a coastal marine environment. J plankton Res 15: 1075-1086

22. Hartmann HJ, Taleb H, Aleya L, Lair N (1993) Predation on ciliates by the suspensionfeeding calanoid copepod Acanthodiaptomus denticornis. Can J Fish aquat Sci 50: 13821393

23. Havskum H, Riemann B (1996) Ecological importance of bacterivorous, pigmented flagellates (mixotrophs) in the Bay of Aarthus, Denmark. Mar Ecol Prog Ser 137: 251263

24. Héral M (1987) Shellfish Culture Development and Management - Aquaculture International Seminar, La Rochelle 4-9 mars 1985. Evaluation of the carrying capacity of molluscan shellfish ecosystems. IFREMER, Brest

25. Jonsson PR, Tiselius P (1990) Feeding behaviour, prey detection and capture efficiency of the copepod Acartia tonsa feeding on planktonic ciliates. Mar Ecol Prog Ser 60: 35-44

26. Kahl A (1931) Die Tierwelt Deutschlands und der angrenzenden Meeresteile. Urtiere oder Protozoa. Dahl F., Dahl M., Bischoff H., Hamburg

27. Klaveness D (1992) Augmentation of the food supply for oyster larvae via bacterivorous flagellates: possible implications for larval breeding and oyster pond management. Aquaculture and Fisheries management 23: 591-597

28. Korringa P (1976) Farming the cupped oysters of the genus Crassostrea. A multidisciplinary treatise. Developments in Aquaculture and Fisheries Science, 2, Elsevier Scient. Publ. Comp., Amsterdam

29. Landry MR, Hassett RP (1982) Estimating the grazing impact of marine microzooplankton. Mar Biol 67: 283-288

30. Landry MR, Kirshtein J, Constantinou J (1995) A refined dilution technique for measuring the community grazing impact of microzooplankton with experimental tests in the central equatorial Pacific. Mar Ecol Prog Ser 20: 53-63

31. Leakey RJG, Burkill PH, Sleigh MA (1994) A comparison of fixatives for the estimation of abundance and biovolume of marine planktonic ciliate populations. J Plankton Res 16: 375-389

32. Leakey RJG, Burkill PH, Sleigh MA (1996) Planktonic ciliates in the northwestern Indian Ocean: their abundance and biomass in waters of contrasting productivity. J Plankton Res: 18: 1063-1071

33. Le Gall S, Bel Hassen M, Le Gall P (1997) Ingestion of a bacterivorous ciliate by the oyster Crassostrea gigas: protozoa as a trophic link between picoplankton and benthic suspension-feeders. Mar Ecol Prog Ser 152: 301-306

34. Lee JJ, Hutner SH, Bovee EC (1985) An illustrated guide to the protozoa eds Allen Press, USA, $615 \mathrm{p}$

35. Lovejoy C, Vincent WF, Frenette JJ, Dodson JJ (1993) Microbial gradients in a turbid estuary: application of a new method for protozoan community analysis. Limnol Oceanogr 38: 1295-1303

36. Malone TC, Ducklow HW (1990) Microbial biomass in the coastal plume of Chesapeake Bay: phytoplankton-bacterioplankton relationships. Limnol Oceanogr 35: 296-312

37. Nezan E (1996) Surveillance du phytoplancton marin: manuel illustré adapté à la formation des analystes. IFREMER $77 \mathrm{p}$

38. Ohman MD, Snyder RA (1991) Growth kinetics of the omnivorous oligotrich ciliate Strombidium sp.. Limnol Oceanogr 36: 922-935 
39. Paulmier G (1997) Tintinnides (Ciliophora, Oligotrichida, Tintinnina) de l'atlantique boréal, de l'océan indien et de quelques mers adjacentes: Mediterranée, mer Caraïbe, mer Rouge. Inventaires et distribution. Observations basées sur les loricas. IFREMER 126 pp

40. Pierce RW, Turner JT (1994) Plankton studies in Buzzards Bay, massachusetts, USA. III. Dinoflagellates, 1987 to 1988. Mar Ecol Prog Ser 112: 225-234

41. Pomeroy LR (1974) The ocean's food web, a changing paradigm. Bioscience 24:499-504

42. Putt M, Stoecker DK (1989) An experimentally determined carbon:volume ratio for marine "oligotrichous" ciliates from estuarine and coastal waters. Limnol Oceanogr 34: 1097-1103

43. Ricard M (1987) Atlas du phytoplancton. Eds du CNRS, vol. 2, 297 p

44. Riisgård HU (1988) Efficiency of particle retention and filtration rate in 6 species of North east American bivalves. Mar Ecol Prog Ser 45:217-223

45. Rincé Y (1978) Intervention des diatomées dans l'écologie des claires ostréicoles dans la baie de Bourgneuf. PhD Biologie Marine, Nantes, 203 p

46. Robert JM, Maestrini SY, Dréno JP, Gonzalez-Rodriguez E (1979) Estimation au moyen de tests biologiques de la fertilité pour trois diatomées des eaux des claires à huîtres de Vendée. Oceanol Acta 2: 275-286

47. Robert JM (1983) Fertilité des eaux des claires ostréicoles et verdissement : utilisation de l'azote par les diatomées dominantes. PhD Sciences Nantes

48. Sanders RW, Porter KG, Bennett SJ, DeBiase AE (1989) Seasonal patterns of bacterivory by flagellates, ciliates, rotifers and cladocerans in a freshwater community. Limnol Oceanogr 34: 673-687

49. Sherr EB, Sherr BF, Paffenhöfer GA (1986) Phagotrophic protozoa as food for metazoans: a "missing" trophic link in marine pelagic food webs? Mar Microb Food Webs 1: $61-80$

50. Sherr BF, Sherr EB, Fallon RD (1987) Use of monodispersed, fluorescently labeled bacteria to estimate in situ Protozoan bacterivory. Appl Environ Microbiol 53: 958-965

51. Sherr BF, Sherr EB, Pedros-Alio C (1989a) Simultaneous measurement of bacterioplankton production and protozoan bacterivory in estuarine water. Mar Ecol Prog Ser 54: 209-219

52. Sherr EB, Rassoulzadegan F, Sherr BF (1989b) Bacterivory by pelagic choreotrichous ciliates in coastal waters of the NW Mediterranean Sea. Mar Ecol Prog Ser 55: 235-240

53. Sherr EB, Sherr BF (1994 a) Bacterivory and herbivory: key roles of phagotrophic protists in pelagic food webs. Microb Ecol 28: 223-235

54. Sherr EB, Caron DA, Sherr BF (1994 b) Staining of heterotrophic protists for visualisation via epifluorescence microscopy. In: Kemp PF, Sherr BF, Sherr EB, Cole JJ (eds) Handbook of Methods in Aquatic Microbial Ecology. Lewis Publishers, Boca Raton, Ann Arbor, London, Tokyo, pp 213-227

55. Shumway SE, Cucci TL, Newell RC, Yentsch CM (1985) Particle selection, ingestion, and absorption in filter-feeding bivalves. J Exp Mar Biol Ecol 91:77-92

56. Sime-Ngando T, Juniper K, Vézina A (1992) Ciliated protozoan communities over Cobb Seamount: increase in biomass and spatial patchiness. Mar Ecol Prog Ser 89: 37-51

57. Sime Ngando T, Gosselin M, Roy S, Chanut JP (1995) Significance of planktonic ciliated protozoa in the Lower St Lawrence Estuary: comparison with bacterial, phytoplankton and particulate organic carbon. Aquat Microb.Ecol 9: 243-258

58. Stoecker DK (1998) Conceptual models of mixotrophy in planktonic protists and some ecological and evolutionary implications. Europ J protistol 34: 281-290

59. Sournia A (1986) Atlas du phytoplancton marin. Eds du CNRS, vol.1, 219 p 
60. Turpin V, Robert JM, Goulletquer P (1999) Limiting nutrients of oyster pond seawaters in the Marennes-Oléron region for Haslea ostrearia: applications to the mass production of the diatom in mesocosm experiments. Aquat Living Resour 12: 335-342

61. Zanette Y (1980) Intervention de quelques facteurs dans l'évolution de la biomasse des claires de Marennes-Oléron. Cons Inst Exp Mer C M L 45: 11p

62. Zubkov MV, Sleigh MA (1995) Ingestion and assimilation by marine protists fed on bacteria labeled with radioactive thymidine and leucine estimated without separating predator and prey. Microb Ecol 30: 157-170 